\title{
Clinical Reasoning: A 47-year-old man with diffuse white matter disease and rapidly progressive dementia
}

Daniel G. Di Luca, MD, Jonathan Landman, MD, Melissa R. Ortega, MD, Sakir Humayun Gultekin, MD, and Xiaoyan Sun, MD, PhD

Neurology ${ }^{\circledR}$ 2019;92:e2832-e2837. doi:10.1212/WNL.0000000000007655
Correspondence

Dr. Di Luca

Daniel.garbindiluc@

jhsmiami.org

\section{Section 1}

A 47-year-old right-handed man without previous medical history presented to the University of Miami Memory Disorder Clinic for evaluation of progressive cognitive decline over a period of 4 months. He was initially noticed to have difficulty in finding his keys and documents and was not able to recall whether he had eaten lunch or dinner. The patient also had word-finding difficulties as well as remembering the meaning of a specific word. Upon further questioning, he also endorsed experiencing poor concentration and difficulty carrying out familiar tasks and for this reason he had to stop working. Additionally, there was also a reported weight loss of 20 pounds over the last 4 months. There was no known family history of dementia.

Mental status examination revealed cognitive impairment, and initial Montreal Cognitive Assessment (MoCA) test score was 15 out of 30 ( -4 in executive function, -5 in attention, -4 in delayed recall, additional recall with cues, and -2 in orientation). It showed a broad spectrum of cognitive impairment involved in cognitive domains of executive function, attention, memory, and orientation. There was no focal neurologic finding on examination.

\section{Questions for considerations:}

1. What is your initial approach to investigation?

\section{GO TO SECTION 2}




\section{Section 2}

Rapidly progressive dementias (RPD) are generally defined as dementia that occurs in less than 1-2 years from initial onset, although no formal definition exists. The initial assessment includes a careful medical history and examination, while considering potential reversible etiologies. Given that the most common causes of RPD are prion diseases, followed by neurodegeneration, autoimmune disorders, cerebrovascular diseases, infections, malignancy, toxic-metabolic encephalopathy, and psychiatric disease, an initial work-up usually includes an extensive laboratory testing to identify infectious etiologies and antibodies in the serum and CSF. ${ }^{1}$ Basic laboratorial data analysis is an important step in the early workup to avoid unnecessary and expensive testing. MRI brain with/without contrast is recommended for the evaluation of space-occupying lesions, infections, and cortical ribboning, and EEG may also be considered to rule out seizure activity and periodic sharp waves, commonly seen in CreutzfeldtJakob disease.

In our case, initial laboratory testing for reversible causes of dementia was negative and within normal limits, including a comprehensive metabolic panel, HIV, syphilis, unrinalysis, lyme disease, TSH, and vitamin B12 levels. Serum autoimmune markers analysis revealed positive antinuclear antibodies with a speckled pattern (titer 40) and antidouble stranded DNA antibodies (7; upper limit 5). MRI brain with/without contrast demonstrated abnormal nonenhancing FLAIR signal in a gyriform manner involving the frontal and occipital lobes without restricted diffusion. There was also abnormal FLAIR signal in subcortical and periventricular white matter with involutional changes more than expected for age (figure), and not in a typical location for MS. An EEG was normal. Owing to the concern for an infectious or inflammatory etiology in the CNS, a lumbar puncture was performed. CSF study showed normal cell count, protein (48) and glucose level (73) with 6 positive oligoclonal bands. CSF cultures and viral encephalitis panel were negative.

\section{Questions for considerations:}

1. What etiologies would you consider in the differential diagnosis?

2. What further tests can be performed for evaluation of $\mathrm{RPD}$ in a young patient? 
Figure MRI brain comparison prior and after treatment and brain biopsy findings

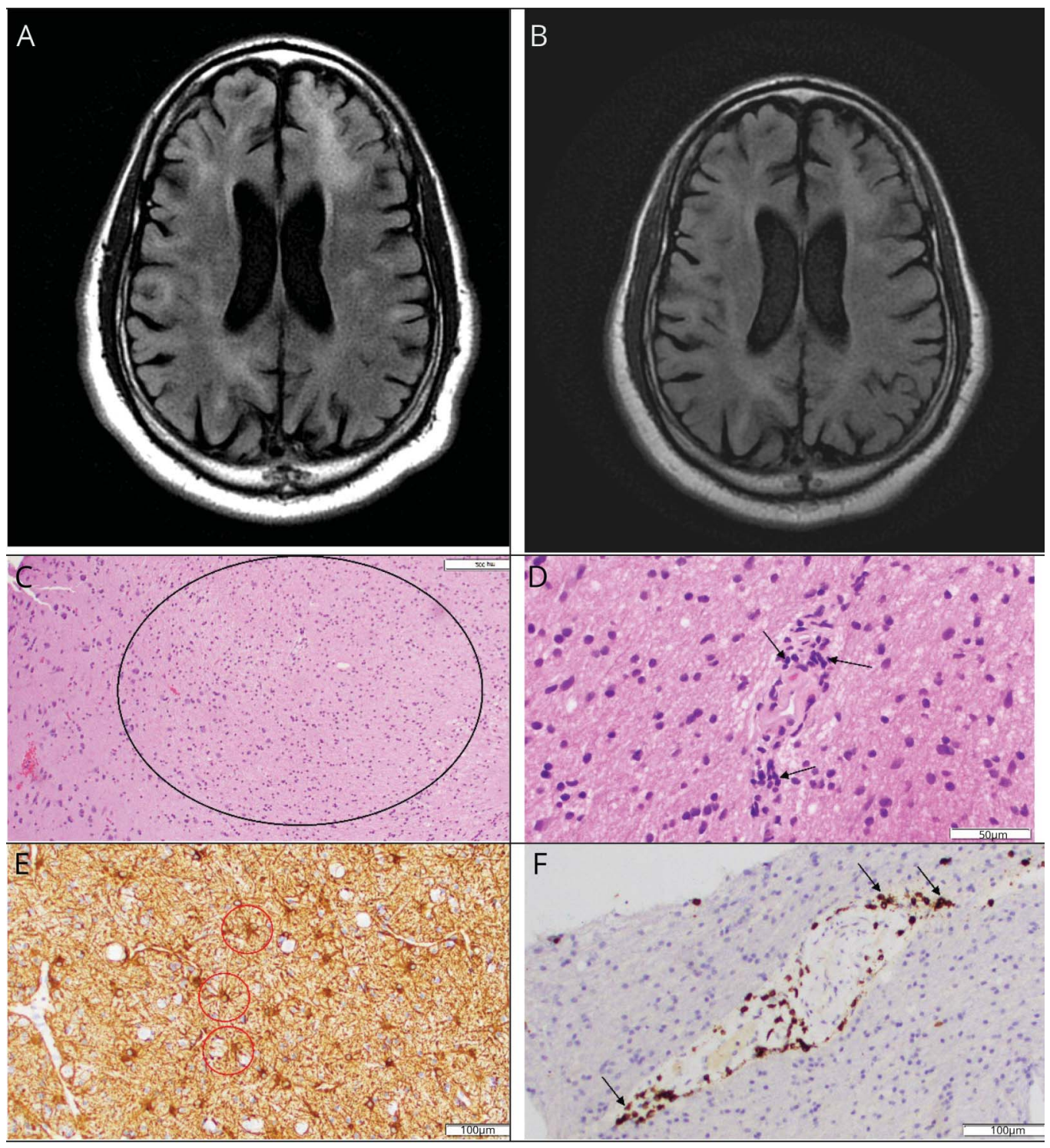

MRI brain T2 FLAIR before (A) and after (B) treatment with steroids. Biopsy: (C) H\&E staining, the circle showing white matter gliosis. (D) H\&E staining, the arrows showing scant perivascular mature lymphocytes. (E) GFAP immunostaining, the circles showing the reactive gliosis. (F) T cell marker CD3 (+) immunostaining, the arrows showing lymphocytes around the blood vessels. 


\section{Section 3}

Owing to the combination of dementia onset at a young age and weight loss, a paraneoplastic syndrome was suspected. A serum paraneoplastic antibody panel revealed a positive voltage-gate calcium channel (VGCC) antibody (>30), and an extensive work-up for malignancy was negative, including whole-body PET scan, endoscopy, and abdominal MRI for any inconclusive findings. To rule out CNS vasculitis, neurosarcoidosis, lymphoma, and storage disease, a brain biopsy of the lesion located on the right subfrontal lobe was performed. In general, a brain biopsy is indicated when an extensive noninvasive work-up has been nondiagnostic.
Additionally, in young patients when a treatable cause is suspected, neuropathologic tissue diagnosis should always be considered. ${ }^{2}$ In our patient, brain biopsy revealed nonspecific white matter gliosis with rare perivascular and parenchymal mature T cells. There were no atypical glial cells, lymphoma, macrophages, granulomas, inclusions, or axonal spheroids. There was no evidence of intraneuronal abnormal deposits. The tissue was also negative for SV40, Congo Red, HSV-1, and CMV (figure).

\section{Questions for considerations:}

1. What is your final diagnosis and what treatments can be performed?

\section{GO TO SECTION 4}




\section{Section 4}

Based on the patient's medical history of rapidly progressive dementia, seropositive voltage-gated calcium channel antibody status, 6 oligoclonal bands in CSF and nonspecific inflammatory pathology in brain tissue, autoimmune dementia was diagnosed. The patient was started on IV methylprednisolone $1 \mathrm{~g}$ for 5 days. Following initial treatment, patient's cognition was markedly improved (MoCA score was 20/30 compared to $15 / 30$ prior to treatment). A repeat MRI brain with/without contrast demonstrated improvement in the abnormal white matter FLAIR signal (figure).

\section{Discussion}

VGCCs are activated upon depolarization of cell membrane and facilitate calcium influx, which initiates many important cellular physiologic events. ${ }^{3}$ Positive VGCC antibodies in serum or CSF are associated with several neurologic disorders. ${ }^{4}$ Most commonly, VGCC antibodies are associated with neuromuscular diseases, such as Lambert-Eaton syndrome $e^{5}$ or with paraneoplastic conditions, notably cerebellar degeneration associated with small cell lung cancer. ${ }^{6}$ Here, we report a rare case of a patient with rapidly progressive dementia associated with VGCC antibody, which should lead to the consideration of a diagnosis of autoimmune dementia as it may respond to immunotherapy.

Although autoimmune dementia related to various antibodies is a well-recognized neurologic disorder, dementia associated with VGCC antibody is rare. A large cohort study of Mayo Clinic showed that VGCC antibodies were detected in 236 (3.4\%) of the 6,842 neurologic patients tested. ${ }^{4}$ Among those VGCC positive patients, 18 (7.6\%) of the 236 patients had degenerative dementia. Another retrospective study reported that 4 cases $(5.6 \%)$ of the 72 patients with autoimmune dementia had positive VGCC antibodies. ${ }^{7}$ These cases, along with ours, suggest that dementia associated with VGCC antibodies is a rare but important autoimmune neurologic phenotype of dementia.

This patient presented with a broad spectrum of cognitive impairment with particular involvement in the cognitive domains of memory, visuospatial function, executive function, and attention. These findings suggest that the VGCC autoantibody may lead to diffuse damage of cerebral regions as voltage-gated calcium channels are widely distributed in cerebral and cerebellar regions. ${ }^{8}$ These functional deficits are supported by brain lesions demonstrated by MRI, along with white matter abnormality, and mild to moderate atrophy in parietal, frontal, and temporal lobes.

The dementia phenotype in our description is different from another reported case of dementia with seropositive VGCC antibody, which described a patient with cognitive loss mimicking frontotemporal dementia. ${ }^{9}$ The mechanism underlying different dementia phenotypes associated with the same VGCC antibodies remains unknown. In our patient, brain biopsy of a white matter lesion showed nonspecific gliosis, perivascular and parenchymal mature $\mathrm{T}$ cell, which suggests a neuroinflammatory response associated with VGCC antibody.

Treatment of autoimmune dementia with immunotherapy including IV methylprednisolone or IVIG has been reported. ${ }^{7}$ Our patient received a 5-day course of IV methylprednisolone with an immediate improvement in cognition. Supporting this clinical finding, MRI brain showed improvement of white matter hyperintensity after treatment (figure). These findings corroborate a prior case series of dementia associated with VGCC antibody that had good response to immunotherapy. ${ }^{4}$

In general, autoimmune dementias are a broad category of conditions; therefore, prognosis may range from complete remission to a relapse-remitting course. Because of the rarity of this disease which is often undiagnosed or underrecognized, there is limited evidence to support the use of clinical markers or to definitely assess prognosis. ${ }^{10}$ In the specific case of dementia associated with VGCC, the responsiveness to immunotherapy is generally considered a good prognostic marker with reports of normal cognition after this specific treatment. ${ }^{4}$

To date, there has not been clear evidence that follow-up imaging is required, although it is generally accepted that most patients need close monitoring with frequent imaging to rule out a primary malignancy. ${ }^{1}$ Our patient has been continuously followed at our clinic, with no malignancy being found to date with serial CT scans of chest and abdomen (around 1 year after initial diagnosis). A whole-body PET scan was initially negative, but was not repeated considering patient's preference and financial limitations. Although we agree that most individuals with autoimmune dementias may benefit from frequent imaging, we also face a challenge to frequently monitor these patients, especially considering the high cost of the indicated tests.

In conclusion, RPD secondary to non-paraneoplastic autoimmune encephalopathies are rare but are more frequently recognized due to advances in detecting antibodies. ${ }^{4}$ Our case describes a young patient with white matter disease and rapidly progressive dementia associated with VGCC antibody in the absence of detected malignancy. Although a single association of positive antibody with dementia may not prove causality, extensive and exhaustive work-up for other conditions were negative, suggesting that positive VGCC antibody is the most likely mediator to initiate disease progress. Positive response to immunotherapy supports that autoimmunity is the underlying pathogenic mechanism. Clinical recognition of autoimmune dementia and initiation of immunotherapy are critical for favorable neurologic outcome in these patients. 


\section{Study funding}

No targeted funding reported.

\section{Disclosure}

The authors report no disclosures relevant to the manuscript. Go to Neurology.org/N for full disclosures.

\section{Appendix Authors}

\begin{tabular}{|c|c|c|c|}
\hline Name & Location & Role & Contribution \\
\hline $\begin{array}{l}\text { Daniel } \\
\text { Garbin Di } \\
\text { Luca, MD }\end{array}$ & $\begin{array}{l}\text { Department of } \\
\text { Neurology, University } \\
\text { of Miami Miller School } \\
\text { of Medicine }\end{array}$ & Author & $\begin{array}{l}\text { Review of the } \\
\text { literature, obtaining } \\
\text { patient consent, and } \\
\text { drafting the case } \\
\text { report. }\end{array}$ \\
\hline $\begin{array}{l}\text { Jonathan } \\
\text { Landman, } \\
\text { MD }\end{array}$ & $\begin{array}{l}\text { Department of } \\
\text { Neurology, University } \\
\text { of Miami Miller School } \\
\text { of Medicine }\end{array}$ & Author & $\begin{array}{l}\text { Review of the } \\
\text { literature, obtaining } \\
\text { patient consent, and } \\
\text { drafting the case } \\
\text { report. }\end{array}$ \\
\hline $\begin{array}{l}\text { Melissa R. } \\
\text { Ortega, } \\
\text { MD }\end{array}$ & $\begin{array}{l}\text { Department of } \\
\text { Neurology, University } \\
\text { of Miami Miller School } \\
\text { of Medicine }\end{array}$ & Author & $\begin{array}{l}\text { Critically reviewing the } \\
\text { manuscript }\end{array}$ \\
\hline $\begin{array}{l}\text { Sakir } \\
\text { Humayun } \\
\text { Gultekin, } \\
\text { MD }\end{array}$ & $\begin{array}{l}\text { Department of } \\
\text { Pathology, University } \\
\text { of Miami Miller School } \\
\text { of Medicine }\end{array}$ & Author & $\begin{array}{l}\text { Critically reviewing the } \\
\text { manuscript }\end{array}$ \\
\hline
\end{tabular}

Appendix (continued)

\begin{tabular}{|c|c|c|c|}
\hline Name & Location & Role & Contribution \\
\hline $\begin{array}{l}\text { Xiaoyan } \\
\text { Sun, MD, } \\
\text { PhD }\end{array}$ & $\begin{array}{l}\text { Evelyn F, McKnight } \\
\text { Brain Institute, Brain } \\
\text { Endowment Bank, } \\
\text { Department of } \\
\text { Neurology, University } \\
\text { of Miami Miller School } \\
\text { of Medicine }\end{array}$ & Author & $\begin{array}{l}\text { Critically reviewing } \\
\text { and editing the } \\
\text { manuscript and final } \\
\text { approval of the } \\
\text { version to be } \\
\text { published. }\end{array}$ \\
\hline
\end{tabular}

\section{References}

1. Geschwind MD, Shu H, Haman A, Sejvar JJ, Miller BL. Rapidly progressive dementia. Ann Neurol 2008;64:97-108.

2. Schott JM, Reiniger L, Thom M, et al. Brain biopsy in dementia: clinical indications and diagnostic approach. Acta Neuropathol 2010;120:327-341.

3. Nanou E, Catterall WA. Calcium channels, synaptic plasticity, and neuropsychiatric disease. Neuron 2018;98:466-481.

4. Zalewski N, Lennon VA, Lachance DH, Klein CJ, Pittock SJ, McKeon A. P/Q- \& N-type calcium channel antibodies: oncological, neurological \& serological accompaniments. Muscle Nerve 2016;54:220-227.

5. Fukunaga H, Engel AG, Lang B, Newsom-Davis J, Vincent A. Passive transfer of Lambert-Eaton myasthenic syndrome with IgG from man to mouse depletes the presynaptic membrane active zones. Proc Natl Acad Sci USA 1983;80:7636-7640.

6. Mason WP, Graus F, Lang B, et al. Small-cell lung cancer, paraneoplastic cerebellar degeneration and the Lambert-Eaton myasthenic syndrome. Brain J Neurol 1997;120: 1279-1300.

7. Flanagan EP, McKeon A, Lennon VA, et al. Autoimmune dementia: clinical course and predictors of immunotherapy response. Mayo Clin Proc 2010;85:881-897.

8. Snutch TP, Peloquin J, Mathews E, McRory JE. Molecular Properties of VoltageGated Calcium Channels [Internet]. Landes Bioscience; 2013. Accessed September 13, 2018. August 21, 2018.

9. Younes K, Lepow LA, Estrada C, Schulz PE. Auto-antibodies against P/Q- and N-type voltage-dependent calcium channels mimicking frontotemporal dementia. SAGE Open Med Case Rep 2018;6:2050313X17750928.

10. McKeon A, Lennon VA, Pittock SJ. Immunotherapy-responsive dementias and encephalopathies. Continuum (Minneap Minn) 2010;16:80-101. 


\section{Clinical Reasoning: A 47-year-old man with diffuse white matter disease and rapidly progressive dementia \\ Daniel G. Di Luca, Jonathan Landman, Melissa R. Ortega, et al. \\ Neurology 2019;92;e2832-e2837 \\ DOI 10.1212/WNL.0000000000007655}

\section{This information is current as of June 10, 2019}

Updated Information \& Services

References

Subspecialty Collections

Permissions \& Licensing

Reprints including high resolution figures, can be found at: http://n.neurology.org/content/92/24/e2832.full

This article cites 9 articles, 1 of which you can access for free at: http://n.neurology.org/content/92/24/e2832.full\#ref-list-1

This article, along with others on similar topics, appears in the following collection(s):

All Clinical Neurology

http://n.neurology.org/cgi/collection/all_clinical_neurology All Cognitive Disorders/Dementia

http://n.neurology.org/cgi/collection/all_cognitive_disorders_dementia Assessment of cognitive disorders/dementia

http://n.neurology.org/cgi/collection/assessment_of_cognitive_disorder s_dementia

Autoimmune diseases

http://n.neurology.org/cgi/collection/autoimmune_diseases

Paraneoplastic syndrome

http://n.neurology.org/cgi/collection/paraneoplastic_syndrome

Information about reproducing this article in parts (figures,tables) or in its entirety can be found online at:

http://www.neurology.org/about/about_the_journal\#permissions

Information about ordering reprints can be found online:

http://n.neurology.org/subscribers/advertise

Neurology ${ }^{\circledR}$ is the official journal of the American Academy of Neurology. Published continuously since 1951 , it is now a weekly with 48 issues per year. Copyright @ 2019 American Academy of Neurology. All rights reserved. Print ISSN: 0028-3878. Online ISSN: 1526-632X.

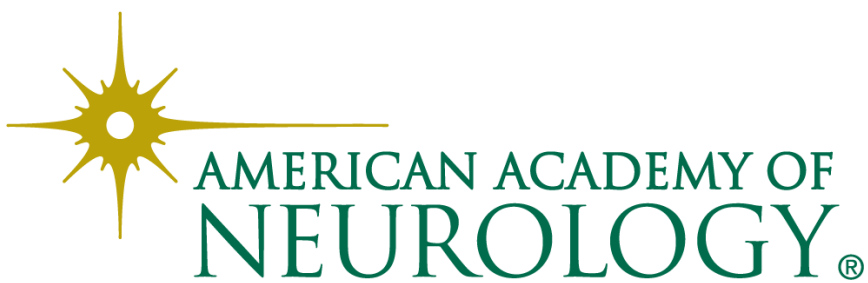

